University of Warwick institutional repository

This paper is made available online in accordance with

publisher policies. Please scroll down to view the document

itself. Please refer to the repository record for this item and our

policy information available from the repository home page for

further information.

To see the final version of this paper please visit the publisher's website. Access to the published version may require a subscription.

Author(s): Watson, Matthew

Article Title: What makes a market economy? Schumpeter, Smith and Walras on the coordination problem

Year of publication: 2005

Link to published version:

http://dx.doi.org/10.1080/13563460500144710

Publisher statement: None 


\title{
'What Makes a Market Economy? Schumpeter, Smith and Walras on the Coordination Problem'
}

\author{
Matthew Watson
}

Published in New Political Economy, 10 (2), 2005, 143-161.

Winner of one of the three Templeton Enterprise Awards given in February 2007 at the Princeton Club in New York for the best article published worldwide in 2005 on the question of humane political economy in an era of globalisation. 


\section{'What Makes a Market Economy? \\ Schumpeter, Smith and Walras on the Coordination Problem'}

Introduction

The tradition of modern political economy is founded upon attempts to show how a market economy of autonomous individuals can function smoothly in the absence of a central authority to coordinate economic activity. This has become known, for obvious reasons, as the coordination problem. As suggested by the title of this article, to confront the coordination problem is to focus upon the question, 'what makes a market economy?'. In the pages that follow, I argue that the answer to such a question lies not, as we might expect, in the realm of economics, but in that of moral philosophy. In order to sustain this argument, I revisit debates about the essence of the market economy which are to be found in the history of economic thought literature, but which are almost entirely ignored by modern economists.

A broad reading of the history of economic thought literature throws up some important findings. For a start, it shows that no successful attempt has ever been made to resolve the coordination problem at the level of pure economics. Indeed, by careful consideration of the most celebrated of such attempts - that undertaken by Léon Walras 
over successive editions of his Eléments d'Économie Politique Pure - we might well be drawn to the conclusion that the coordination problem is fundamentally irresolvable at that level. The question, 'what makes a market economy?', may therefore not be an economic question at all.

If this is true, then important public policy implications follow. Perhaps most profoundly, there can be no purely economic justification for establishing institutions that are designed specifically to introduce market relations into social life: at least, not that can be captured in the standard demand and supply diagrams of textbook economics. ${ }^{1}$ It is common fare for political economists to assert that market institutions have politically regulating effects on social life. However, this tends to be countered by the acknowledgement that such effects are intimately tied to economic relations that can be justified in their own terms: i.e., as a precursor to increased economic dynamism and increased economic efficiency. The debate about market relations takes on a completely different dimension if it can be shown that these secondary claims lack substance and, in fact, there is no purely economic justification for incorporating individuals into market relations. In such circumstances, the question of establishing market institutions becomes a purely political question.

In order to arrive at this conclusion, I draw upon the work of the two most important economic theorists to have attempted to resolve the coordination problem. One, as previously alluded to, is Léon Walras, and the other is Adam Smith. The analyses of the two men differ in one important respect. Walras's attempted resolution of the 
coordination problem is situated at the level of pure economics and, in this way, he asks the question, 'what makes a market economy?', only after having already assumed that a market economy exists. He takes the presence of market institutions as a given, and only then does he begin to explore how a market economy of autonomous individuals derives its stability in the absence of a central authority to coordinate economic activity.

For Smith, by contrast, the coordination problem must be resolved before market institutions are introduced as a regulatory mechanism for social life. He attempts to specify the conditions under which we can expect a smoothly functioning economy to result from the incorporation of individuals into a system of market relations. As such, he asks the question, 'what makes a market economy?', without having made the prior assumption that a market economy already exists. The conditions under which market institutions will prove operable are not economic conditions at all, but relate to the constitution of the individual as a moral being. For Smith, then, the resolution of the coordination problem takes place at the level of moral philosophy.

The very possibility that this might be the case tends to be lost within modern reinterpretations of the history of economic thought. The modern tendency is to cleanse political economy of its preoccupation with questions of moral philosophy, in order to create a discipline of pure economics. Looking specifically at the coordination problem, Joseph Schumpeter's History of Economic Analysis represents the seminal work of this nature. In section one of what follows, I show how Schumpeter reduces the coordination problem to the level of pure economics by redrawing the intellectual lineage between 
Smith and Walras, such that Smith is consciously re-positioned as a proto-Walrasian. In so doing, Smith's own attempt to treat the coordination problem as a matter of moral philosophy is, in effect, written out of the history of economic thought for not being sufficiently 'economic' in its explanatory content. In section two I restate Smith's original position on the coordination problem, and in section three I contrast this with Walras's avowedly economic writings on the same theme. In the final section, I discuss the implications of Walras's ultimately unsuccessful attempts to resolve the coordination problem at the level of pure economics. It is here that I explore the possibility that there are no purely economic justifications for establishing institutions with the sole intention of incorporating individuals into market relations.

\section{Schumpeter and a Walrasian Reading of Smith}

Joseph Schumpeter sets the tone for the modern understanding of Adam Smith's contribution to the history of economic thought in his magisterial overview of the canon, History of Economic Analysis. ${ }^{2}$ Schumpeter himself was schooled in the Walrasian tradition, and he reduces Smith's contribution to momentary flashes of inspiration which, with hindsight, can be read as a forerunner of what we today understand as Walrasian themes. Schumpeter is by no means alone in this general endeavour. Smith's work has been subjected to any number of attempts at creative 'reading in', whereby modern 
political economists from different theoretical backgrounds have all supposedly shown that the history of economic thought runs in a linear fashion from past to present, leading directly from Smith to themselves. As Jacob Viner observed in an essay written to mark the $150^{\text {th }}$ anniversary of the publication of The Wealth of Nations, "Traces of every conceivable sort of doctrine are to be found in that most catholic book, and an economist must have peculiar theories indeed who cannot quote from The Wealth of Nations to support his special purposes”. ${ }^{3}$

However, if Schumpeter is in good company in attempting to read into The Wealth of Nations what he wants to read into it, his was a novel attempt to read Smith specifically as a Walrasian. In Schumpeter's hands, Smith's contribution is merely to identify the broad outlines of the intellectual puzzles that Walras subsequently creates the analytical tools to solve. Schumpeter's aim is to reconstruct the history of economic thought, such that intellectual progress within the discipline is measured solely in terms of the extent to which it develops as a science that is indisputably Walrasian in its underlying conception. Set within such a context, the only contribution that Smith can make to the history of economic thought is in those moments in which his thoughts can subsequently be represented with the imprint of Walrasian themes. Schumpeter portrays the whole of preWalrasian theory in terms of the help it provides for Walras to specify the central problem of economic analysis as a problem of pure economics: that of how decentralised markets coordinate individual economic activities. 
Content to judge him solely on such grounds, Schumpeter argues that the only aspect of Smith's thought that deserves to be of interest for modern-day economists is Chapter VII of Book One of The Wealth of Nations. In that chapter, Smith outlines his famous distinction between market prices and natural prices. Market prices are those that have to be paid to execute the everyday process of exchange. Natural prices, by contrast, are those that reflect the true value of the good being exchanged, as determined by the cost of factor inputs alone. Schumpeter focuses on Smith's view of the relationship between market prices and natural prices and, in particular, on one phrase that Smith uses to capture the essence of that relationship. Smith argues that, all other things being equal, the natural price is that to which market prices are "continuously gravitating". ${ }^{4}$

Schumpeter reads into the suggestion of an implicit mechanism that will enforce convergence between market and natural prices what he calls a "rudimentary equilibrium theory". ${ }^{5}$ However, the concept of 'equilibrium', despite being a common part of economic discourse in the 1770s, is almost entirely overlooked by Smith. ${ }^{6}$ It appears only once in the whole of The Wealth of Nations. Schumpeter's depiction of Smith as a 'rudimentary equilibrium theorist' is therefore to assign a meaning to Smith’s work that, in all likelihood, Smith himself was consciously trying to avoid.

Moreover, that meaning itself relies upon the important intervention of an intermediary. Schumpeter suggests that Smith's contribution to the history of economic thought rests on the influence that Chapter VII of Book One of The Wealth of Nations had on Walras's thought, even though Walras himself draws upon Say's re-working of Smith's Chapter 
VII, rather than Smith’s original. ${ }^{7}$ In Donald Winch’s ironic précis of Schumpeter's position, Chapter VII was only “a good chapter because it enabled Jean-Baptiste Say to write a better one that was, in turn, to prove an inspiration to Léon Walras”. 8

Modern-day economists have found much intellectual comfort in Schumpeter's rather crude dismissal of Smith's overall contribution to the history of economic thought. For a start, it reduces economics to the study of simple equilibrium states, removing from the analysis any need to empirically verify actually existing economic conditions, in favour of stipulating logical propositions. As Nicholas Kaldor suggests in his seminal article, 'The Irrelevance of Equilibrium Economics', equilibrium economics is mathematical economics. The latter, in turn, rests solely on the elucidation of basic assumptions which, while refined as a study of pure logic, takes the economic content of the analysis no further than the starting point of the initial assumptions. ${ }^{9}$

Second, Schumpeter's attempt to downplay Smith's contribution to the history of economic thought allows modern-day economists to undertake their endeavour without regard to Smith's wider writings. Schumpeter is dismissive not only of the analysis contained within The Wealth of Nations, but of the whole tradition of political economy that Smith represented. He insists that "the garb of philosophy is removable ... in the case of economics”. ${ }^{10}$ By contrast, Smith’s work was rooted in moral philosophy and his prior philosophical reflections are constitutive of his economic enquiry. 
Smith's aim was to understand the way in which different forms of economic life impacted upon, and threatened to subvert, the moral principles that underpinned a functioning society and a harmonious social life free from injustice. ${ }^{11}$ Such principles cannot be condensed into a simple model of equilibrium economics, nor can they be explained solely through the use of formal mathematical logic. It is true that Smith invoked a gravitational mechanism to describe the relationship between market and natural prices, as it is true that a gravitational mechanism is amenable to study using mathematical methods. Yet, he also suggests, as an addendum to the passage in which he appealed to the image of a gravitational mechanism, that "different accidents may sometimes keep [market prices] suspended a good deal above [the natural price], and sometimes force them down even somewhat below it”. ${ }^{12}$ As a consequence, and unlike the gravitational mechanism that arises in the natural world, there is no automatic trigger for the gravitational mechanism in Smith's economic world. The intervening influence of his 'accidents' confirm as much.

Such 'accidents' also appear in the first three editions of Walras's Eléments d'Économies Politique Pure, in those moments in which Walras discusses trading at disequilibrium prices. In Walras, however, Smith’s 'accidents' take a strictly economic form. They result from economic agents misreading the signals emerging from the price system and, as a consequence, miscalculating their purely economic considerations of costs and benefits. The same sort of purely economic calculation does not appear anywhere in Smith. His concern is, in fact, precisely the opposite. It is to demonstrate the indivisibility of political economy and moral philosophy. As such, the economic effect, 
that of the failure of market prices always to conform to the natural price, or what modern-day economists call the failure of the market's equilibrating mechanism, cannot have a purely economic cause. Therefore, the question of how decentralised markets coordinate individual economic activities through the price mechanism cannot be resolved solely at the economic level. For Smith, the gap between market and natural prices has its origins in the moral basis of society. The failure of market prices always to converge on the natural price represents a failure to socialise all individuals into the just principles that create a society devoid of harm. If market prices are above the natural price, this is symptomatic of a commodity market in which goods are being sold above their true value. In such circumstances, and Smith wrote at length in the later books of The Wealth of Nations about why we might experience such circumstances, producers are exercising power over consumers.

From Smith's perspective, such power is illegitimately exercised, in that it harms the consumers who have to pay in excess of the natural price. A society that tolerates a price structure in which market and natural prices diverge is therefore a society that tolerates unjust relations at the inter-personal level. As a consequence, it is also a society that lacks the instinct for propriety, which Smith believed to be at the core of equable communal relations. ${ }^{13}$

Despite what are clearly significant differences within the analytical systems of Smith and Walras, Schumpeter's reading of the history of economic thought, which posits Smith as a proto-Walrasian, has been highly influential amongst the economics 
profession. Indeed, for a large proportion of modern-day economists, trained as they are in Walrasian general equilibrium theory, Schumpeter's account of Smith's contribution to the history of economic thought has become the way to read The Wealth of Nations. It has also become the reason not to read his earlier Theory of Moral Sentiments. ${ }^{14}$ The result has been numerous attempts either to judge Smith on his failure to specify the basis of a fully worked out general equilibrium theory, ${ }^{15}$ or to selectively read the origins of general equilibrium theory back into Smith. ${ }^{16}$ Such attempts are almost entirely misguided. According to Winch, they serve no useful purpose, for the simple reason "that Smith was not trying very hard to be a general equilibrium theorist". Any attempt to read strict Walrasian themes into Smith's work therefore runs the risk of "sequential anachronisation”, ${ }^{17}$ as Smith's classical political economy concerns are made to fit the rather different concerns of modern-day economists. Schumpeter's herculean efforts to re-write the history of economic thought from a distinctively Walrasian perspective have acted as a Procrustean bed for Smithian political economy.

In the following section, I attempt to reinstate Smith's original position on the coordination problem. Smith's proposed resolution of the coordination problem focuses on the moral constitution of the individual economic agent. He specifies a set of moral conditions under which, and only under which, a market economy of autonomous individuals can function smoothly in the absence of a central authority to coordinate economic activity. Such conditions require for the development of the individual to have reached the level at which every member of society's first moral instinct is to forego the self-interested alternative in order to ensure that others are treated with propriety. In Part 
VII of the Theory of Moral Sentiments, Smith comes close to acknowledging that these conditions refer to an imagined utopia, rather than to a real-life possibility. Immediately, then, we should be aware that a latent scepticism is evident in Smith in relation to the market economy.

Solving the Coordination Problem through Moral Principles? Smith's 'Impartial Spectator

For Smith, the key to understanding the unique nature of the human species is to be found in the capacity for imagination that human beings are able to display. ${ }^{18}$ To live life without imaginatively reconstructing the situation in which others find themselves is to fail to exercise our full human capacities. According to Smith, we only become truly conscious of ourselves in those moments in which we are conscious of our relationships, both real and imagined, with other people. ${ }^{19}$

This must be contrasted with much modern economics that claims to be derived directly from Smith, in which the decision to act without concern for other people is the core principle of economic decision-making. This was a view of economic agency that Walras was content to endorse. Yet, for Smith, such a view is to deny the truly human element of the self. To behave in a purely self-interested manner is to corrupt the moral 
basis of the self that is called upon to act in such a way. As a consequence, the economic agent that acts in a purely self-interested manner is not a truly human agent. On the very first page of The Wealth of Nations, Smith makes the strikingly obvious point that all economic activity occurs within society. ${ }^{20}$ So long as this remains true, the pure selfinterest of Walrasian thought experiments cannot be the underlying motivation for economic activity. ${ }^{21}$ Neither, then, and contrary to so many modern interpretations of Smith, ${ }^{22}$ can it be the means through which individual behaviour is coordinated, such that it coheres into a functioning market economy.

The only way in which this could be so is if the market economy takes shape somehow beyond society. This was not a possibility that Smith took seriously, though, because he was adamant both that the market economy was a human creation and that all human life occurs within the context of society. In two passages from the Theory of Moral Sentiments, Smith makes explicit reference to life lived in "some solitary state", "without any communication with society". However, those references are prefixed by the clauses, "were it possible" and "if it was possible", showing that he believed that living life alone was a purely hypothetical state of being. ${ }^{23}$ At any particular moment of time, an individual is involved in numerous relationships with other individuals within society. The key to maintaining those relationships is the mutual respect that arises from each member of society treating every other with propriety. For Smith, the market economy has no essential features of its own. It is merely an aggregation of the social relationships of which it is constituted. The key to maintaining the market economy is therefore the same as that of maintaining its constituent parts. In the absence of deeply ingrained 
moral instincts for propriety, a smoothly functioning market economy is not a possibility. From a Smithian perspective, the introduction of market institutions can never be justified, unless it is within a context in which all economic agents are already fully socialised with the instinct for propriety.

This, of course, is an exceptionally exacting standard. Indeed, so exacting is it that Smith acknowledges that society might never reach the stage where it is populated by such pristine individuals. The Theory of Moral Sentiments depicts two possible end-states for the individual. One is the type of person we might become if we are able to subjugate all the selfish passions to the concern for acting with propriety. The other is the type of person we might become if instead we follow the most basic acquisitive tenets of market society. Contained within these two types of person we find a basic contradiction within market life.

On the one hand, the market economy, with its spectacle of riches and its constant appeal to desires that might be satisfied, has a potentially corrupting influence on individuals who allow themselves to be enveloped by the alluring images and the limitless wants of the commercial way of life. Without an obsessive admiration for wealth, which arises from the moral corruption of the individual and leads the corrupted individual to demand goods solely to satisfy the 'deception' of worthless desires, ${ }^{24}$ the market economy would be deprived of its vibrancy and its dynamism. On the other hand, the automatic reproduction of a market society can only proceed following the constitution of uncorrupted individuals who act instinctively with propriety. The coordination problem - 
which, for Smith of course, is a problem of society not of the economy - has no resolution in the absence of such pristine individuals. As such, there is a requirement for some form of central authority to impose the coordination structures that would otherwise be missing. The contradiction of market life can therefore be easily stated: the moral character of the individuals who provide the market economy with its dynamism is itself an impediment to the automatic reproduction of market society.

In the Theory of Moral Sentiments, Smith focuses on the latter part of this contradiction and, in particular, on how the pristine individual might emerge from the corruptible individual. It is here that he places great significance on the human imagination. He suggests that it is from our capacity for the imaginative reconstruction of the condition of others that we derive a sense of justice. ${ }^{25}$ This is important, because Smith believes that a society lacking an ethical code rooted in a sense of justice is a society that cannot function in any meaningful sense. ${ }^{26}$

It may well be a society which, on the surface, appears to permit flourishing forms of economic life. However, below these surface appearances, this will be a society in which economic relations are systematically exploitative and in which the self-interested use of political power is necessary in order to reproduce such exploitative relations. In the absence of just treatment of all individuals within the economy, Smith argues that a selfreproducing market structure cannot be assured in the face of the incentives that merchants and manufacturers have to collude with one another in an attempt to exploit society as a whole. ${ }^{27}$ The coordination problem is only resolved in circumstances in 
which the social relations of production are subjected to routine self-reproduction. Yet, for Smith, this relies on the willingness and the ability of individuals both to internalise concerns for justice into their most basic elements of cognition and to embody those concerns in their everyday practices. ${ }^{28}$ In an often cited passage from the Theory of Moral Sentiments, Smith writes that: "Justice is the main pillar that upholds the whole edifice. If it is removed, the great, the immense fabric of human society [including the market economy that is a feature of such a society] ... must in a moment crumble into atoms”. 29

For Smith, our sense of justice is a manifestation of our ability to experience what he moves between calling 'sympathy' and 'fellow feeling' for the needs of others. ${ }^{30}$ Fellow feeling relies on the imaginative reconstruction of the social circumstances of other people. The fact that we are able to imaginatively reconstruct the needs of others confirms that we will simultaneously have a means of anticipating the relative propriety of our actions. Our actions are most likely to pass other people's tests of propriety if they have first passed our own, especially in circumstances in which our own tests are based on the imaginative reconstruction of the form that other people's tests will take. It is our own imagination, then, that acts as a moral compass to guide our actions.

For Smith, our imagination takes the form of an 'impartial spectator', and it is the impartial spectator that holds the key to the resolution of the coordination problem. According to Smith, we are answerable to the impartial spectator as our conscience. ${ }^{31}$ It is at the instigation of our conscience that we are able to sympathise with the condition of 
others. In effect, the impartial spectator exercises will over us, and it is through its exercise of will that we act in a manner that is appropriate to the emotions that our sympathies evoke. $^{32}$

The impartial spectator is not only a part of the self, it is that part of the self that allows the individual to experience what it is to be truly human. In the absence of situations in which it is possible to effect conscience, the life that Smith depicts for us is a solitary life in which we are never morally whole, because we have no active frames of reference against which to judge the propriety of our actions. What, then, are we to make of a market economy that becomes a context for actions that are not prompted by the impartial spectator? If we take Smith's argument seriously, it will be an economy that imposes dehumanising effects upon those who operate within it. In addition, so long as the market economy is populated by conscious human agents eager to assert themselves as autonomous moral beings, it will also be an economy that cannot experience routine selfreproduction.

The existence of market institutions appears to offer incentives for individuals to act in an increasingly self-interested manner. Certainly, the reward structure embedded by market institutions provides enhanced levels of material well-being for those who act on the basis of instrumental rationality (i.e., doing what they want to do solely through concern for themselves). By contrast, no such automatic increases in material well-being follow for those who act on the basis of deontological rationality (i.e., doing what they think they ought to do in the interests of society as a whole). ${ }^{33}$ If instrumental rationality is to 
dominate deontological rationality, individuals have to disable the impartial spectator in order to ignore its promptings to act out of concern for others. However, for Smith, the presence of a fully active and fully activated impartial spectator is a necessary precondition for the resolution of the coordination problem.

Does this mean, then, that Smith believed the coordination problem to be fundamentally irresolvable in economies that are constructed on the basis of market institutions? This is not a question to which he delivers a definitive answer, but it is certainly something that is implied by his work. For Smith himself, the issue was not to assume the prior existence of market institutions as a prelude to asking whether such institutions created conditions that led automatically to the resolution of the coordination problem. He asked instead about the type of economic agents that needed to be in existence if the coordination problem was to be resolved, and then he explored how such agents could be constituted as moral beings. Insofar, though, as market institutions socialise individuals into self-interested patterns of behaviour, it is unlikely that they provide the context for instilling the deontological rationality that Smith believed to be at the heart of the resolution of the coordination problem. 
Solving the Coordination Problem through Pure Economics? The Walrasian 'Auctioneer'

By the time that Walras was writing, most economists had dismissed Smith's concerns, and ascribed purely self-interested character traits to their economic agents in order to construct economic problems that were mathematically tractable. Walras worked within such a tradition and, for him, attempts to resolve the coordination problem as a series of algebraic equations could only proceed once the starting assumption of pure self-interest had already been made.

Despite these significant differences in starting assumptions, however, Walras's original concern is no less to derive a representation of a just economy than is Smith's. ${ }^{34}$ Walras's models of the economy operate to the standard of 'justice in exchange', whereby distributional neutrality at the moment of exchange ensures that the distribution of endowments preceding exchange is retained after the exchange is complete. ${ }^{35} \mathrm{He}$ is keen to stress that this standard renders his models purely hypothetical, as all instances of exchange have distributional consequences in the context of self-interested economic agents. ${ }^{36}$ At no stage does he claim that his theoretical models are simple reflections of the exchange system as it occurs in practice.

This does not mean, however, that he believed his theoretical models to be irrelevant to the study of real life. The role they played was to state, in formal terms, the conditions that had to be in place if the criterion of justice in exchange was to be satisfied. As Jan 
Van Daal and Albert Jolink argue, Walras was hoping to do more than merely 'mathematicise' the coordination problem by showing that the criterion of justice in exchange had a mathematical solution. ${ }^{37}$ His adoption of the rigour of formal mathematical logic highlights a concern to provide universal benchmarks against which it is possible to decide whether the introduction of market institutions should be tolerated by society. Walras begins his investigation of the coordination problem with social questions foremost in mind. The pure economics of Les Eléments is merely a means of commenting on the encroachment of market institutions into social life and, in particular, a means of passing judgement on the acceptable limits of the subjugation of social existence to the market economy.

The concept of 'tâtonnement' is central both to Walras's pure economics and to his wider social concerns. This is a word that has no direct translation from French to English but, as a concept, it is used to depict the process through which the price mechanism 'gropes' its way towards a structure of equilibrium prices. ${ }^{38}$ This sense of groping has been the subject of intense discussion within the secondary literature, but most historians of economic thought agree that it is synonymous with the determination of prices. Any resolution of the coordination problem requires that the condition of justice in exchange is met, which in turn requires that the determination of prices takes place in the absence of distributional consequences for the economy as a whole. Given that prices are formed via groping, this means that it is the precise characteristics of the tâtonnement process that determine whether or not the coordination problem is resolved. 
However, it is difficult to know exactly how to use Walras's concept of tâtonnement to resolve the coordination problem, because we find that there are two distinct notions of tâtonnement in his work. The Walras of the first three editions of Les Eléments conceptualises the process of tâtonnement within the context of a disequilibriumproduction model. Here, it is prices that are subjected to the dynamics of groping. Each time that production occurs at a level that is not optimal for the economy as a whole, exchange takes place at disequilibrium prices. Equilibrium prices only arise over time, when producers learn more about optimum levels of output and, as a consequence, they engage in equilibrium production. In such circumstances, the observed temporal trend in prices is that of successive attempts to get closer to the equilibrium price before finally arriving at it. All this is an anathema, though, to the Walras of the fourth edition of Les Eléments, which is now generally regarded as his definitive statement. In this edition, Walras conceptualises the process of tâtonnement within the context of a pledges model that rules out disequilibrium production by definition. It may take time for all market participants to arrive at a structure of pledges that is consistent with equilibrium prices. However, as soon as this is achieved, all production and all exchange then takes place instantaneously at equilibrium prices. ${ }^{39}$

Walras's reworking of his own concept of tâtonnement has significant implications for the way in which we think about the coordination of economic activity. His original understanding, in which disequilibrium trading takes place as an iterative process, occurs across time, as individual market actors grope their way towards equilibrium prices through everyday exchange activities. As such, it is an abstraction designed to capture 
the history of the equilibrating process. By contrast, the tâtonnement of the fourth edition, in which disequilibrium exchange is defined away, occurs at a single moment of time, as all transactions take place simultaneously at equilibrium prices. If we are attentive to Walras's insistence that we focus on the economy's price dynamics, then his removal of the temporal dimension of price determination in this latter model leaves us, somewhat paradoxically, with a tâtonnement without groping. At most, he provides an abstraction designed to capture the mechanism of a single equilibration moment. ${ }^{40}$

Walras's reworked account of the tâtonnement process had an important impact on subsequent theoretical developments within economics. Perhaps most obviously, it liberated the study of the coordination problem from Smith's philosophical concern for the motivations of the individual economic agent. The individual disappears from a purely mechanistic interpretation of a single moment of equilibration and, as such, questions about the constitution of the individual as a moral agent are rendered entirely redundant.

Yet, this does not mean that Walras bypasses the crux of Smith's analysis of the coordination problem simply to take a successful analytical short-cut to its resolution. Indeed, from the perspective of the coordination problem, Walras's reworked concept of tâtonnement appears to be self-defeating. At the very least, it leaves fundamentally unexplained that which he set out to explain in the first place. An equilibrium position is assumed in the fourth edition of Les Eléments, but never actually demonstrated. The Walras of edition four takes us no closer than the Walras of the first three editions to 
understanding the means through which individual economic activity is coordinated in line with the existence of equilibrium. In fact, it could be said that the Walras of edition four takes us further away. Throughout the first three editions of Les Eléments, Walras suggests that the resolution of the coordination problem lies somewhere in the process of the determination of prices but, by the fourth edition, he has stopped thinking of the determination of prices as a process. It is little wonder, then, that he is unable to tell us where, precisely, within the price mechanism that the resolution of the coordination problem is to be found.

Walras's actual accomplishments are much more limited. He is successful in solving a system of simultaneous equations in order to determine, mathematically, what the condition of equilibrium would look like were it to arise. Yet, this is at the expense of explaining the dynamic processes that take the economy towards equilibrium. This remains resolutely indeterminate in Walras's formulation ${ }^{41}$ and, as such, the coordination problem remains resolutely unresolved.

By edition four of Les Eléments, Walras may even have given up trying to resolve the coordination problem as a matter of pure economics. The changes he makes in the fourth edition suggest that he was only attempting to demonstrate how the impersonal mechanism of pure competition in a perfect market serves to regulate behaviour in a manner that is analogous to formal coordination. His original aim was transformed until it became merely that of specifying the economic equivalent of a solution which, to cite the noted Walras scholar, William Jaffé, "only a computer-like intellectus angelicus 
knowing all the parameters could arrive at algebraically". ${ }^{42}$ It was left to others to embody such an intellectus angelicus in the form of a fictitious person: the Walrasian auctioneer. It is unclear exactly where the auctioneer metaphor originates, although we can be clear, following Donald Walker, that the construction is not Walras's own. ${ }^{43}$ Perhaps the best that we can do is to follow the suggestion in Franklin Fisher's contribution to The New Palgrave Dictionary of Economics, in which he attributes the auctioneer metaphor to lectures delivered by Schumpeter, with Samuelson subsequently bringing it into the written literature. ${ }^{44}$

For current purposes, though, the origins of the metaphor are of secondary importance. What is more significant is that the real-time interpretation of the tâtonnement process founders on the introduction of the clearly mythical auctioneer. ${ }^{45}$ The auctioneer can have no real-world equivalent, as it is an "economy-wide market secretary", ${ }^{46}$ who presides over a single market that incorporates all known economic activity. It is somehow both internal to the market (insofar as it condenses all information relevant to transacting on the market), yet external to it (in the sense that the auctioneer itself is disinterested in the distributional effects of market outcomes). The role of the auctioneer is twofold. First, it carries all market-sensitive information simultaneously to all market participants. Second, it cries out the equilibrium price, at which point production and exchange not only become possible, but are actually carried out. ${ }^{47}$ In the absence of the auctioneer crying out the equilibrium price, no production or exchange can occur. Therefore, without the auctioneer centrally receiving and disseminating all price information, the market economy is a logical impossibility. ${ }^{48}$ 
The auctioneer may appear to resolve the coordination problem, insofar as the coordination problem is explained away in its presence. But, by being forced to invoke such a construction in order to explain away the problem, Walras is in fact admitting that it defeated him. The tâtonnement process of the first three editions of Les Eléments was an attempt to resolve the coordination problem at the level of pure economics. Walras's original intention was to show how individual actions, some situated on the demand-side of the economy and some on the supply-side, created effects that were the functional equivalent of a market machine grinding out equilibrium prices. ${ }^{49}$ However, by allowing something akin to an auctioneer to set equilibrium prices beyond the scope of individual activities, Walras stipulates no pure economic mechanism for resolving the coordination problem in the fourth edition of Les Eléments.

Solving the Coordination Problem through Mathematics: The Shaky Foundations of Market Economics?

Many important implications follow from Walras's ultimately unsuccessful attempts to show that coordination is possible in the context of an in-time model in which disequilibrium trading is permitted. It is his inability to demonstrate that the coordination 
of market activity is an exclusively economic issue that leads to his revisions between the first three and the fourth editions of Les Eléments and, in particular, to the introduction of the mechanism which others have understood as the auctioneer. As Frank Hahn notes in a revealing overview of the Walrasian tradition, without the auctioneer, "we are faced with the necessity of specifying precisely the forces which shape the producers' demand for goods, and in particular how this demand reacts to [price] signs”. ${ }^{50}$ However, this is the economics of the coordination problem. The introduction of the auctioneer to explain market outcomes serves the rather paradoxical purpose of crowding out the economic explanation of the derivation of market activity.

The auctioneer metaphor is not an explanation couched at the level of pure economics. Rather, it is a means of sidestepping the need to detail the economic dynamics through which activities are coordinated in decentralised markets. To add the auctioneer to a theoretical model of the economy is to remove the economics from the model. We must be clear that the auctioneer metaphor is an attempt to paper over the cracks in Walras's system. As Michel De Vroey argues, it is no longer a matter of dispute that "Walras failed to provide an explicit complete account of the institutional hypothesis underlying his mathematical models". ${ }^{51}$ Such an assertion is now taken as given among the community of Walras scholars. De Vroey's 'institutional hypothesis’ relates to the factors that underpin supply and demand within market economies, so it is here that the economics of the coordination problem are to be found. But it is exactly this that is lost in a purely mathematical exposition of the coordination problem. 
This in itself is no reason to dismiss Walras's conclusions. Nor is it reason to dismiss the significance of his study. However, it does make it necessary to think carefully about how we interpret his economics. It is not merely the case that Walras's economics fails to solve the coordination problem. It could be that he shows the coordination problem to be irresolvable as a matter of pure economics. At the very least, the only solution he is capable of offering is a mathematical solution.

For Walras, the line of reasoning is as follows: equilibrium and, along with equilibrium, the solution to the coordination problem, is first established "in principle"; then, and only then, can it be established "in effect". ${ }^{2}$ The fact that equilibrium can be established in principle is not sufficient for establishing it in effect, but unless the former condition can be satisfied it is certain that the latter cannot. Walras's system of simultaneous equations - indeed, the whole of his mathematical exposition in the fourth edition - is designed only to prove that equilibrium is a logical possibility. It does not prove that it is an actual state of the world.

The presumption amongst most Walras scholars is that his revisions in the fourth edition are an acknowledgement on his part that it is impossible to demonstrate equilibrium in effect. As a consequence, he gave up on this goal in order to concentrate solely on delivering a logical proof that equilibrium could exist in principle. He goes to great lengths in the preface to the fourth edition to draw his readers' attention to the purely hypothetical nature of his system: he calls it "this fiction". 53 Walras exorcises disequilibrium transactions and production from his analytical framework, so that his 
mathematical equations can maintain not only their purity, but their very validity. ${ }^{54}$ As Manuel Luís Costa suggests, Walras finally came to the conclusion that he had no choice but to understand tâtonnement "as pertaining to the mathematical demonstration of general equilibrium. What he eventually obtained was an algorithmic or iterative solution to the problem solved by the system of equations". ${ }^{55}$ Put simply, the economic 'results' are contained in the founding assumptions of how the system behaves. While this is fine as a study of pure logic, it provides no knowledge of the economic dynamics that lead decentralised markets to equilibrium.

Moreover, to the extent that this is true of Walras's own work, it is also true of the Walrasian tradition as a whole. Mathematical developments in general equilibrium economics have tended to concentrate on solving the logical puzzles that the mathematical economists have themselves created. ${ }^{56}$ No new knowledge of the workings of actual economies can therefore be inferred. The Walrasian tradition has been more successful in asking new questions to which its mathematical models have a ready-made answer, than it has been in providing new answers to the enduring questions of political economy. ${ }^{57}$ The most fundamental of these questions, that relating to the coordination problem, is no exception. So long as coordination takes place across disequilibrium transactions as well as equilibrium transactions, the Walrasian tradition has nothing to say. Any recognition of the existence of disequilibrium trading corrupts the clarity and the precision of the mathematical exposition. ${ }^{58}$ 
What we are left with, then, is a market model that is able to elucidate a mathematical system, rather than a mathematical model that is able to explain the market system. ${ }^{59}$ The explanation contained within the fourth edition of Les Eléments relates to Walras's simultaneous equations rather than to the institutional basis of the economy. ${ }^{60}$ However, in solving those equations, while Walras might not provide us with a specification of economic dynamics, he does provide us with facts that are relevant to the way in which we understand the economy. Walras's mathematics shows the ever more restrictive assumptions that have to be made before equilibrium can be demonstrated, even in principle. Such restrictions become even more exacting before it is possible to fulfil the subsequent task, that of demonstrating equilibrium in effect. These are also the outcomes to emerge from modern general equilibrium analysis. Here, the results tend to be almost wholly negative, in that the analysis proves that the result of general equilibrium is merely a reflection of the highly unrealistic assumptions on which the analysis is based. General equilibrium, which corresponds to the full realisation of the resolution of the coordination problem, is patently not a generic feature of the world. ${ }^{61}$

Walras's economics may fail in its own terms. Yet, he does provide important guidelines against which to judge whether the introduction of market institutions will lead to coordinated economic activities set within the context of justice in inter-personal relations. Walras shows that there is no reason, rooted solely at the level of pure economics, to suggest that this will ever be the outcome of the operation of real economies. In other words, there is no strictly economic justification for the introduction of market institutions. 
In no way does Walras's elaborate mathematical exposition prove the superiority of market economies: not as a matter of mathematics, nor as a matter of logic, and certainly not as a matter of economics. It is closer to the truth to say that it has exactly the opposite effect. As Albert Jolink suggests, this may not be entirely surprising, given that Walras gave no thought to constructing his general equilibrium models as a crude apologism for market capitalism ${ }^{62}$. Walras's economic models are a thought experiment only, ${ }^{63}$ and the thoughts they should elicit are ones that encourage us to be sceptical about the introduction of the institutions of the market economy. This is especially so when the rationale for introducing market institutions is given in purely economic terms. No such reading of Walras can be forthcoming if one accepts as the starting point Schumpeter's view of the history of economic thought. Nonetheless, it is a reading that deserves careful consideration.

To give one example of why this might be so, let us consider the development agenda of the World Bank and the International Monetary Fund. By distancing ourselves from Schumpeter's Walrasian history of economic thought, and by focusing instead on Walras's failure to resolve the coordination problem as a matter of pure economics, the justification for all manner of World Bank and IMF interventions rapidly falls apart. The political conditionalities that accompany development assistance all serve to deepen the process of institutionalising the market economy. IMF stabilisation packages require developing countries to overwrite established economic customs in an attempt to create the structures of the market economy, ${ }^{64}$ while World Bank development loans are 
increasingly oriented towards reconstituting the individual economic agent with marketbased cognition and rationalities. ${ }^{65}$ But what are we to make of such interventions in light of the foregoing analysis?

The usual critique of existing development programmes is that market institutions cannot be expected to function smoothly if they are simply parachuted onto society from above. It tends to be assumed that they have to be truly instituted, in the literal sense of being established in an organic manner from within society. The foregoing analysis, however, provides us with an additional dimension to the critique. It suggests that it matters not whether market institutions arise in an organic manner from within society. Even in circumstances such as these, the fact that the coordination problem appears to be fundamentally irresolvable at the level of pure economics still implies that there is no basic economic rationale for the introduction of market institutions.

Another example may help to reinforce this point. We observe numerous cases around the world in which a society consents to the continued reproduction of market life once the institutions of the market economy have become firmly incorporated into everyday experience. But this does nothing to alter the more fundamental existential point being made here. It matters not whether popular consent is forthcoming for the reproduction of market institutions, not even if consent is given specifically on the grounds that market societies deliver enhanced levels of economic dynamism and material well-being. Even in circumstances such as these, there would have been no basic economic rationale for the introduction of market institutions in the first place. 
This conclusion reaches to the very core of what it means to theorise the market economy. Moreover, it is likely to be somewhat troubling for those whose theories of the market economy are situated at the level of pure economics. If we admit the possibility that there is no basic economic rationale for the introduction of market institutions, then economic theories will be unable to offer more than superficial insights on the one subject where we would assume that economists have plausible claims to specialist knowledge: how markets work.

\section{Conclusion}

The analysis contained in the previous sections suggests that the key questions of political economy may be unanswerable if we restrict our search for answers to the theories and methods of economics. The constitutive problem of political economy is contained within the question, 'what makes a market economy?'. Most of the seemingly successful attempts to offer purely economic answers to this question have followed the Walrasian tradition of general equilibrium analysis. Yet, if I am in any way correct in this article, these have to be seen as largely Pyrrhic victories. For a start, the general equilibrium approach presents its theories of the market economy in mathematical, rather than economic, terms. Indeed, it has tended to empty theories of the market economy of 
any economic explanation whatsoever. The apparent success in resolving the coordination problem in fact relates to the ever more restrictive economic assumptions that have to be made if theories of the market economy are to retain their internal coherence.

The conclusions to be drawn from the general equilibrium approach are, in almost all instances, negative. They show that pure economic theories of the market are largely devoid of useful economic content, except for demonstrating the counterfactual that there is no strictly economic justification for the introduction of market institutions into everyday economic life. The theory of the market remains ill-formed and underdetermined at the level of pure economics. ${ }^{66}$

This brings us right back to the beginning of modern political economy, to the crucial question of how economic analysis should proceed. In particular, I suggest, it returns us to the need to reclaim Adam Smith's intellectual legacy from Schumpeter's attempt to rewrite the history of economic thought from a distinctively Walrasian perspective. Smith tries every bit as hard as Walras to stipulate the conditions under which a market economy of autonomous individuals can function smoothly in the absence of a central authority to coordinate economic activity. Significantly, however, his views on this issue are settled prior to writing The Wealth of Nations, the book that is generally understood to be the progenitor of pure economics. Smith therefore suggests that the coordination problem has to be resolved before pure economic analysis can begin. His attempts at such a resolution are focused at the level of moral philosophy. 
To ask the question, 'what makes a market economy?', is to focus on the constitution of the individual economic agent as a moral being and to engage with normative issues relating to the structuring of society. As these core concerns of political economy were exorcised in the turn towards pure economics, to ask the question, 'what makes a market economy?', is patently not the precursor for documenting the successes of pure economics. Rather, it serves only to highlight the mistaken nature of attempts to formalise the pioneering economics of Adam Smith by subjecting it to the rigours of mathematical logic. If our aim is to explain how markets work, then the history of pure economics is one of an extended detour. We have come a long way to reach the point at which it is necessary to argue once again for going back to the beginning and rediscovering a form of economic analysis that reunites political economy and moral philosophy.

\section{Notes:}

This paper was originally presented in March 2004 as part of the General Seminar series at the Political Economy Research Centre at the University of Sheffield. I would like to extend my gratitude to all the participants at the seminar for their positive and constructive comments. In particular, I would like to thank Andrew Gamble, Tony Payne and Jonathan Perraton, whose views on the original paper were influential in helping me to decide how best to rewrite it. I would also like to thank Keith Tribe and two of NPE's anonymous referees for their comments on the rewritten piece, as well as two of my doctoral students, 
Simon Glaze and Paul Lewis, for any number of conversations about the work of Adam Smith. The responsibility for all mistakes, of course, rests with me alone.

${ }^{1}$ I am grateful to one of my anonymous referees for pointing out that I should add this qualification. Austrian process analysis, it could be said, provides an economic justification for the introduction of market institutions even if it is shown that there is no purely economic solution to the coordination problem. However, Austrian theory has always remained very much on the margins of mainstream twentieth century economics, for which the coordination problem is key. For this reason, I am confident that my underlying claim holds, although it is given extra weight by the addition of this qualification.

${ }^{2}$ Joseph Schumpeter, History of Economic Analysis (Oxford University Press, 1994 [1954]).

${ }^{3}$ Jacob Viner, 'Adam Smith and Laissez-Faire', in: John Maurice Clark et al, Adam Smith, 1776-1926: Lectures to Commemorate the Sesquicentennial of the Publication of the 'Wealth of Nations' (Augustus M. Kelley Publishers, 1989 [1928]), pp. 116-55, p. 126.

${ }^{4}$ Adam Smith, An Inquiry into the Nature and Causes of the Wealth of Nations, edited, abridged and with an introduction by Andrew Skinner (Pelican, 1970 [1776]), p. 160.

${ }^{5}$ Schumpeter, History of Economic Analysis, p. 189.

${ }^{6}$ Emma Rothschild, Economic Sentiments: Adam Smith, Condorcet, and the Enlightenment (Harvard University Press, 2001), p. 144.

${ }^{7}$ Léon Walras, Elements of Pure Economics: Or the Theory of Social Wealth, translated by William Jaffé from the fourth edition of Les Eléments d'Économie Politique Pure (Orion Editions, 1984 [1954]), pp. 2017.

${ }^{8}$ Donald Winch, ‘Adam Smith’s Problems and Ours', Scottish Journal of Political Economy, Vol. 44, No. 4 (1997), pp. 384-402, p. 387.

${ }^{9}$ Nicholas Kaldor, 'The Irrelevance of Equilibrium Economics', Economic Journal, Vol. 82, No. 6 (1972), pp. 1237-55, pp. 1237-8.

${ }^{10}$ Schumpeter, History of Economic Analysis, p. 31. 
${ }^{11}$ On which point, see, for instance, Andrew Skinner, A System of Social Science: Papers Relating to Adam Smith (Clarendon Press, 1979); Robert Heilbroner, The Essential Adam Smith (W.W. Norton \& Company, 1986); Samuel Hollander, Classical Economics (Blackwell, 1987).

${ }^{12}$ Smith, Wealth of Nations, pp. 160-1.

${ }^{13}$ See Adam Smith, The Theory of Moral Sentiments, sixth edition, the Glasgow Edition of the Works and Correspondence of Adam Smith, edited by D.D. Raphael and A.L. Macfie (Liberty Fund, 1982 [1790]), I.i.

${ }^{14}$ Of course, there are those who adhere to the so-called 'Adam Smith Problem', who claim that Smith's two major texts are incompatible, and that Smith changed his mind on many of the core aspects of his analytical system between writing The Theory of Moral Sentiments (1759) and The Wealth of Nations (1776). From this perspective, it could be said that there is no need to read The Theory of Moral Sentiments, because this represents the 'old' Smith, who the 'new' Smith laid to rest. However, I do not subscribe to the existence of an 'Adam Smith Problem'. The sixth edition of The Theory of Moral Sentiments was the last that Smith allowed to be published in his lifetime and, whilst it contains many changes to the previous edition, the underlying philosophical themes on which he constructs his view of society remain very much intact. There is no sense in which Smith recants in the sixth edition on any of the major claims about the nature of social existence to be found in the second edition, which was published in 1761, and which itself was a revised version of the original. The sixth edition appeared in 1790, fully fourteen years after he wrote The Wealth of Nations. If the process of writing The Wealth of Nations had caused him to change his mind about the concept of society which appeared in the earlier versions of The Theory of Moral Sentiments, then surely this would have been reflected in the 1790 version of The Theory of Moral Sentiments.

${ }^{15}$ See, for instance, Paul Samuelson, 'The overdue recovery of Adam Smith's reputation as an economic theorist', in: Michael Fry (Ed.), Adam Smith's Legacy: His Place in the Development of Modern Economics (Routledge, 1992), pp. 1-14.

${ }^{16}$ See, for instance, Frank Hahn, 'Reflections on the Invisible Hand', Lloyd's Bank Review, No. 144 (1981), pp. 1-21.

${ }^{17}$ Winch, ‘Adam Smith’s Problems and Ours’, p. 388, p. 386. 
18 The concept of imagination plays a pivotal role in much of Smith's earliest work, which was unpublished during his lifetime. See, for instance, Adam Smith, Lectures on Rhetoric and Belles Lettres, the Glasgow Edition of the Works and Correspondence of Adam Smith, edited by J.C. Bryce (Liberty Fund, 1985); Adam Smith, Essays on Philosophical Subjects, the Glasgow Edition of the Works and Correspondence of Adam Smith, edited by W.P.D. Wightman (Liberty Fund, 1982), in particular, 'The History of Astronomy’, pp. 33-105.

${ }^{19}$ Smith, Theory of Moral Sentiments, II.iii.2.1; see also Daniel Fusfeld, The Age of the Economist, ninth edition (Addison Wesley, 2002), p. 24.

${ }^{20}$ Smith, Wealth of Nations, p. 109.

21 Alan Kirman, 'The Intrinsic Limits of Modern Economic Theory: The Emperor Has No Clothes', Economic Journal, Vol. 99, Conference Proceedings (1989), pp. 126-39, p. 138.

${ }^{22}$ On modern interpretations of Smith, see Pierre Force, Self-Interest Before Adam Smith: A Genealogy of Economic Science (Cambridge University Press, 2003).

${ }^{23}$ Smith, Theory of Moral Sentiments, III.1.3, IV.2.12.

${ }^{24}$ See Ibid. IV.1.10.

${ }^{25}$ Ibid. II.ii.

${ }^{26}$ See, for instance, Kenneth Arrow, 'The division of labor in the economy, the polity, and society', in: Gerald O’Driscoll (Ed.), Adam Smith and Modern Political Economy: Bicentennial Essays on the Wealth of Nations (Iowa State University Press, 1979), pp. 153-64, p. 158.

${ }^{27}$ Hollander, Classical Economics, p. 64.

${ }^{28}$ Hyun-Ho Song, ‘Adam Smith’s Conception of the Social Relations of Production', European Journal of the History of Economic Thought, Vol. 4, No. 1 (1997), pp. 23-42.

${ }^{29}$ Smith, Theory of Moral Sentiments, II.ii.3.4.

${ }^{30}$ Ibid. I.i.3.

${ }^{31}$ Ibid. III.1.4-6.

32 D.D. Raphael and A.L. Macfie, 'Introduction', in: Adam Smith, The Theory of Moral Sentiments, the Glasgow Edition of the Works and Correspondence of Adam Smith, edited by D.D. Raphael and A.L. Macfie (Liberty Fund, 1982), pp. 1-52, p. 16. 
33 John Davis, 'Collective intentionality and individual behavior', in: Edward Fullbrook (Ed.), Intersubjectivity in Economics: Agents and Structures (Routledge, 2002), pp. 11-27.

${ }^{34}$ See, for instance, William Jaffé, ‘The Normative Bias of the Walrasian Model: Walras Versus Gossen’, Quarterly Journal of Economics, Vol. 91, No. 2 (1977), pp. 371-87; Jan Van Daal and Albert Jolink, The Equilibrium Economics of Léon Walras (Routledge, 1993).

${ }^{35}$ Walras, Elements of Pure Economics, pp. 73-80; for a discussion, see Pascal Bridel and Elisabeth Huck, 'Yet Another Look at Léon Walras's Theory of Tâtonnement', European Journal of the History of Economic Thought, Vol. 9, No. 4 (2002), pp. 513-40.

${ }^{36}$ Walras, Elements of Pure Economics, p. 47.

${ }^{37}$ Van Daal and Jolink, The Equilibrium Economics of Léon Walras.

${ }^{38}$ Mark Blaug, Economic Theory in Retrospect, fifth edition (Cambridge University Press, 1997).

${ }^{39}$ On the notion of two Walrases, corresponding to the two different concepts of tâtonnement to be found in his work, see Donald Walker, 'Walras’s Theories of Tatonnement', Journal of Political Economy, Vol. 95, No. 4 (1987), pp. 758-74.

40 On the distinction between Walras’s in-time and atemporal tâtonnement models, see William Jaffé, ‘Walras’s Economics as Others See It', Journal of Economic Literature, Vol. 18, No. 3 (1980), pp. 528-49.

41 This point was originally made as long ago as 1881. See Francis Edgeworth, Mathematical Psychics (Kegan Paul, 1881). For a modern restatement of the same point, see Albert Jolink, The Evolutionist Economics of Léon Walras (Routledge, 1996).

42 William Jaffé, 'Walras' Theory of Tâtonnement: A Critique of Recent Interpretations', Journal of Political Economy, Vol. 75, No. 1 (1967), pp. 1-19.

43 Donald Walker, Walras’s Market Models (Cambridge University Press, 1996).

${ }^{44}$ Franklin Fisher, ‘Adjustment process and stability’, in: John Eatwell, Murray Milgate and Peter Newman (Eds), The New Palgrave: A Dictionary of Economics, Volume I (Macmillan, 1987), pp. 26-9.

45 Manuel Luís Costa, 'Comment on 'Yet Another Look at Léon Walras's Theory of Tâtonnement', European Journal of the History of Economic Thought, Vol. 9, No. 4 (2002), pp. 550-8, pp. 552-3. 
${ }^{46}$ Michel De Vroey, 'Transforming Walras into a Marshallian Economist: A Critical Review of Donald Walker's Walras's Market Models', Journal of the History of Economic Thought, Vol. 21, No. 4 (1999), pp. 413-35, p. 427.

${ }^{47}$ Bruno Ingrao and Giorgio Israel, The Invisible Hand: Economic Equilibrium in the History of Science, translated by Ian McGilvray (MIT Press, 1990).

${ }^{48}$ Roy Weintraub, 'The Microfoundations of Macroeconomics: A Critical Survey', Journal of Economic Literature, Vol. 15, No. 1 (1977), pp. 1-23, pp. 11-12.

${ }^{49}$ Bridel and Huck, 'Yet Another Look at Léon Walras’s Theory of Tâtonnement', p. 528.

${ }^{50}$ Frank Hahn, ‘Some Adjustment Problems’, Econometrica, Vol. 38, No. 1 (1970), pp. 1-17, p. 11.

${ }^{51}$ De Vroey, ‘Transforming Walras into a Marshallian Economist', p. 426.

${ }^{52}$ Walras, Elements of Pure Economics, p. 242.

${ }^{53}$ Ibid. p. 37.

${ }^{54}$ Walker, 'Walras’s Theories of Tatonnement', p. 767.

${ }^{55}$ Costa, 'Comment on 'Yet Another Look at Léon Walras’s Theory of Tâtonnement’', p. 551, emphasis added.

${ }^{56}$ Mark Blaug, The Methodology of Economics: Or How Economists Explain, second edition (Cambridge University Press, 1992), p. 240.

${ }^{57}$ Alan Coddington, 'The Rationale of General Equilibrium Theory', Economic Inquiry, Vol. 13, No. 4 (1975), pp. 539-58.

${ }^{58}$ Bridel and Huck, 'Yet Another Look at Léon Walras’s Theory of Tâtonnement', p. 521.

${ }^{59}$ Jaffé, ‘Walras’ Theory of Tâtonnement’, p. 14.

${ }^{60}$ De Vroey, ‘Transforming Walras into a Marshallian Economist’, p. 416.

${ }^{61}$ See, for instance, Weintraub, 'The Microfoundations of Macroeconomics'; Frank Ackerman, 'Still Dead After All These Years: Interpreting the Failure of General Equilibrium Theory', Journal of Economic Methodology, Vol. 9, No. 2 (2002), pp. 119-39.

${ }^{62}$ Jolink, The Evolutionist Economics of Léon Walras.

${ }^{63}$ Antoine Rebeyrol, “'Yet Another Look'? A Comment', European Journal of the History of Economic Thought, Vol. 9, No. 4 (2002), pp. 541-9, pp. 545-7. 
${ }^{64}$ Laurence Harris, 'Will the real IMF please stand up: what does the Fund do and what should it do?', in: Jonathan Michie and John Grieve Smith (Eds), Global Instability: The Political Economy of World Economic Governance (Routledge, 1999), pp. 198-211.

${ }^{65}$ David Williams, 'Constructing the Economic Space: The World Bank and the Making of Homo Oeconomicus’, Millennium: Journal of International Studies, Vol. 28, No. 1 (1999), pp. 79-99.

${ }^{66}$ Ackerman, 'Still Dead After All These Years’. 